\title{
インターネットのセカンドオピニオン請求の 質問にみる肺癌患者および家族の訴え
}

\author{
秋葉直志 1 - 山下 誠 $1 \cdot$ 佐藤修二 1 ・ \\ 永田 徹 $1 \cdot$ 山崎洋次 ${ }^{1}$
}

要旨一一目的. インターネットを通して受け付けた呼吸器外科関係のセカンドオピニオンを求める質問内容から肺 癌患者あるいは家族の心情や訴えを考察した. 方法. 呼吸器外科, 肺癌のウェッブサイト上にセカンドオピニオンの 請求を受け付けたところ，1998 年 5 月から 2001 年 2 月までの間に 386 人から 430 回の質問があり，これを検討・分析 した. 結果. 電子メールの質問が $87 \%$ を占めた. 質問の病名は原発性肺癌が $79 \%$ を占め, 疑いを加えると $87 \%$ を占 めた. 男性が女性の 1.9 倍であった. 患者年齢は 16 歳から 90 歳で平均が 61.7 歳, 50 歳から 79 歳が $82 \%$ を占めた. 質 問者は男性が女性の 0.94 倍で, 患者の子からが $60 \%$ であった. 内容は今後の治療方針に関するものと標準的治療に関 するものが最多で $59 \%$ ，標準治療以外の治療方針についてが $18 \%$ であった，不満が 67 人 $(17 \%)$ あり，他の病院の情 報を尋ねるのが 55 人 $(14 \%)$ で, その他, 説明が不十分, 入院あるいは手術までの待ち時間が長いなどがあった. 結 論. 患者や家族の質問のほとんどは治療方針に関するものであり, 肺癌などの悪性腫瘍の治療に満足していない. 医師 と患者・家族とのコミュニケーションは良好ながら, 特に子とのコミュニケーションに改善の余地がある. 主治医の治 療方針や説明に不安があり，専門家の意見を望んでいる。（肺癌. 2002;42:589-593）

索引用語 —インターネット, セカンドオピニオン, 肺癌, インフォームドコンセント, 本音を語ること

\section{Requests for Second Opinions Through the Internet Reveal the Feelings and Concerns of Patients With Lung Cancer and Their Families}

\author{
Tadashi Akiba ${ }^{1}$; Makoto Yamashita ; Shuji Sato ${ }^{1}$; \\ Toru Nagata ${ }^{1}$ Y Yoji Yamazaki ${ }^{1}$
}

ABSTRACT - Objective. To gain insight into the feelings and concerns of patients with lung cancer and their families. Method. We announced on our Department of Thoracic Surgery website (http: //www.jikei.ac.jp) and a lung cancer treatment website (http: //www.akiba.gr.jp/tcp/) that we would accept requests for second opinions from patients and their families. We analyzed comments and questions received from May 1998 through February 2001. Results. We received 430 messages by e-mail, telephone, or facsimile concerning 386 patients. Messages concerning $87 \%$ of these patients were sent by e-mail. Of the 386 patients, $79 \%$ had lung cancer and additional $8 \%$ were suspected of having lung cancer. The male-to-female ratio of patients was 1.9: 1 . The patients' ages ranged from 16 to 90 years and the average age was 61.7 years. Eighty-two\% of patients were aged 50 to 79 years. Of the persons sending messages, $60 \%$ were children of patients. The male-to-female ratio of message-senders was 0.94: 1 . A majority of questions (59\%) concerned future plans for medical treatments or standard medical treatments, and $18 \%$ of questions concerned nonstandard medical treatment plans. The messages included 67 complaints, which included requests for information about other hospitals. Questioners often expressed dissatisfaction with incomplete explanations from physicians and the long waiting times for hospitalization or operation. Conclusion. Patients and their families are most often concerned about medical

\footnotetext{
1 東京慈恵会医科大学外科.

別刷請求先：秋葉直志, 東京慈恵会医科大学外科, ₹ $105-8471$

Reprints: Tadashi Akiba, Department of Surgery, The Jikei Uni別刷請求先：秋葉直志，都港区西新橋 3-25-8 (e-mail: akiba@jikei.ac.jp) versity School of Medicine, 3-25-8 Nishishinbashi. Minato-ku, Tokyo 105-8471, Japan (e-mail: akiba@jikei.ac.jp).

${ }^{1}$ Department of Surgery, The Jikei University School of Medicine, Japan.
} 
treatment plans. They are often not satisfied with the treatment of malignant tumors, such as lung cancer. Although the communication between a patient or patient's family and a doctor is relatively good, communication needs to be improved, especially between physicians and patient's children. Patients and their families are often dissatisfied with the explanations or treatment plans of their general practitioner and want to hear the opinion of a specialist. (JJLC. 2002; 42:589-593)

KEY WORDS — Internet, Second opinion, Lung cancer, Informed consent, Truth telling

\section{はじめに}

肺癌の告知がどの程度行われているか, また患者が満 足しているかという問題に対しアンケート調査が行われ ている.1-3 これらのアンケートは通常, 主治医や治療を 受けている医療機関が行っており，患者やその家族とし ては，医師に対して気兼ねし本音を語ることが難しいと 推測される.

インフォームドコンセント（IC）の重要性が声高に語 られているが, IC が患者や家族からみて満足できる状況 か否かを医療従事者側で評価することは至難の業であ り，稀に患者側から発せられるクレームを水山の一角と して現状を推測し，医療関係者は襟を正すように努力す るしかない.

今回われわれは，インターネットを通してセカンドオ ピニオン関連の質問を受け付けた。ここに寄せられた質 問や意見は，第三者の立場のわれわれに語られており， 忌憚のない意見と考えられる．寄せられたセカンドオピ ニオンを求めての質問を検討・分析することにより，患 者や家族が医療を受けながら何に疑問をもち，何を求め ているかを判断する材料とし, さらに今後の診療の心構 えの一助にするために今回の検討を行った。

\section{対象と方法}

ウェッブサイト上にセカンドオピニオン関連の質問を 受け付ける広報を行い, 連絡先の電子メール, FAX 番号 を明記した。匿名でも受付を行った。 ウェッブサイトは 以下の 3 つである.「東京慈恵会医科大学呼吸器外科 (http: //www.jikei.ac.jp)」,「肺がん治療ネット(http: // www.akiba.gr.jp/tcp/)」,「キャンサーネットジャパン (http: //www.nagumo.or.jp/cancer/)」. 1998 年 5 月から
2001 年 5 月までに 451 人から質問があった. 分析対象は 1998 年 5 月から 2001 年 2 月までとした. 1 人から 1 回あ るいは複数回の質問があり, 392 人から 436 回で, 腫瘍性 疾患と無関連な 6 人 6 回を除外し, 386 人 430 回を対象 とした. 分析内容は質問の該当患者の年齢 - 性別 - 診断, 質問の媒体，質問者の年齢・性別 - 患者との関係，質問 内容, クレームである，質問内容やクレームは延べで計 算した。また他の病院を知りたいという質問もクレーム に含めた。情報内容は質問者の申告を使用した。

本研究は東京慈恵会医科大学倫理委員会の許可を得て いる.

\section{結 果}

質問媒体は電子メールが最多の 334 人で $87 \%$ を占め, 次に FAXが 45 人と多かった。手紙と電話は合わせて 7 人であった。

質問の要因となった病名がまったく不明なのは 386 人 中で 10 人であり, 残りの 376 人中で原発性肺癌が 296 人と最多で $79 \%$ を占め, 原発性肺癌疑いを加えると 328 人で $87 \%$ を占めた. 肺癌患者の男女比をみると, 男性が 女性の 1.9 倍であった. 中皮腫が 15 人で, 癌や肉腫の肺 転移や胸腺腫などのその他の悪性腫瘍が 33 人であり, こ れらが $12 \%$ を占めた (Table 1). 患者年齢は 16 歳から 90 歳で平均が 61.7 歳であった. 60 歳から 69 歳の患者が最 も多く 110 人 $(36 \%)$ で, 50 歳から 79 歳が 252 人 $(82$ \%) と大部分を占めた（Table 2).

実際の質問者の男女比は男性が女性の 0.94 倍であっ た. 386 人中患者の子から寄せられた質問が最も多く 232 人で，全体の $60 \%$ であった (Table 3)．質問内容は今後 の治療方針に関する質問と，手術・化学療法・放射線療 法に関する質問が最多で 226 人（59\%）であった（重複

Table 1. Diagnose

\begin{tabular}{lcccccc}
\hline & Lung cancer & $\begin{array}{c}\text { Suspected to } \\
\text { have cancer }\end{array}$ & Mesothelioma & $\begin{array}{c}\text { Other } \\
\text { malignant disease }\end{array}$ & Others & Total \\
\hline Male & 184 & 19 & 10 & 18 & 2 & 233 \\
Female & 97 & 12 & 4 & 12 & 4 & 129 \\
Unknown & 15 & 1 & 1 & 3 & 4 & 24 \\
\hline Total & 296 & 32 & 15 & 33 & 10 & 386 \\
\hline
\end{tabular}


Table 2. Age distribution of the patients

\begin{tabular}{lccrrrrrrrrr}
\hline Age years & $10-19$ & $20-29$ & $30-39$ & $40-49$ & $50-59$ & $60-69$ & $70-79$ & $80-89$ & $90-99$ & Unknown & Total \\
\hline Male & 1 & 3 & 10 & 10 & 34 & 78 & 46 & 8 & 1 & 42 & 233 \\
Female & 1 & 2 & 6 & 9 & 35 & 32 & 27 & 3 & 0 & 14 & 129 \\
Unknown & 0 & 1 & 0 & 0 & 0 & 0 & 0 & 0 & 0 & 23 & 24 \\
\hline Total & 2 & 6 & 16 & 19 & 69 & 110 & 73 & 11 & 1 & 79 & 386 \\
\hline
\end{tabular}

Table 3. Message-sender's gender distribution or their complaints and message-sender's relation to the patient

\begin{tabular}{lccccccc}
\hline Gender or complaints & Patient & Spouse & Brother or sister & Children & Relatives & Others & Total \\
\hline Male & 26 & 15 & 11 & 94 & 8 & 5 & 159 \\
Female & 14 & 24 & 11 & 11 & 5 & 4 & 169 \\
Unknown & 10 & 0 & 0 & 27 & 9 & 12 & 58 \\
\hline Total & 50 & 39 & 22 & 232 & 22 & 21 & 386 \\
\hline Other hospital & 4 & 4 & 5 & 36 & 0 & 6 & 55 \\
Explanation & 0 & 1 & 0 & 11 & 0 & 0 & 12 \\
Waiting & 0 & 1 & 1 & 3 & 0 & 0 & 5 \\
Others & 1 & 1 & 0 & 2 & 0 & 0 & 4 \\
\hline Total & 5 & 7 & 6 & 52 & 0 & 6 & 76 \\
\hline
\end{tabular}

質問でその合計)。さらに, 遺伝子治療, 免疫療法, 民間 療法などの標準治療以外の治療方針に関するものが 68 人 $(18 \%)$ であった。このうち遺伝子治療に関するもの が 40 人であった. その他の質問として, 推薦するあるい は転院先としての良い病院に関するもの 55 人, 現在の病 状に関するもの 49 人，診断を訊いているもの 39 人，予 後を尋ねるもの 39 人, 告知に関する質問が 14 人, 癌治 療に関する情報を求める質問が 16 人であった.

現状に対する不満としては 67 人 $(17 \%)$ あり，他の病 院の情報を知りたいが 55 人 $(14 \%)$ ，医師からの説明が 不十分であるが 12 人 $(3 \%)$ ，入院あるいは手術までの待 ち時間が長いが 5 人，などがあった（Table 3).

\section{考 察}

患者の不満を分析する報告は, 特定の手技の満足度や 癌告知に関するアンケートの検討が散見されたのみであ る. 呼吸器外科や肺癌治療全般に関する検討はなく，ま たアンケートは主治医や治療を受けている医療機関が 行っており，本音を語ることが難しいと推測される.

今回の質問形式として電子メールによるものが最多で あり, FAXが次に多かった。この理由として, インター ネットでセカンドオピニオン関連の質問を受け付けたこ と，ウェッブサイト上でクリックするだけで電子メール が送れる状態をつくって扔いたこと，また質問の宛先と して電子メールと FAX 番号を表示していたことが考え られる。

ほとんどの質問が肺癌に関することであったが，この
理由としてセカンドオピニオン関連の質問受付を広報し た媒体が「東京慈恵会医科大学呼吸器外科」,「肺がん治 療ネット」,「キャンサーネットジャパン」というウェッ ブサイトであり, 癌に関するサイトを 2 つ使用して受け 付けていたためと考える，そして，これらのウェッブサ イトはインターネット上の各種検索エンジンで, 癌や肺 癌のキーワード検索を行うと上位にランクしているから であろう。

質問は患者の子からの質問が $60 \%$ を占めていた. 患者 本人からの質問が最多と予想していたが，予想と異なり 子からの質問の次に位置し,わずか 50 人 (13\%)に留まっ た.配偶者や兄弟姉妹からの質問がこれに次いで多かっ たものの, 本人と配偶者の質問数を合計しても $23 \%$ しか なかった.この理由として, 今回の検討に用いたインター ネットによるウェッブサイトという媒体が現在の悪性腫 瘍を持った年代よりも若い世代により普及していること が考えられる．また癌患者本人や配偶者は，医師と直接 面談し IC を受けるが, 患者の子は医師からの説明を受け る機会が少ないために子と医師間の直接の情報交換が難 しいこと, そして核家族化により親子の間でも情報の疎 通が不十分なことが考えられる。

予想に反して告知や予後に関する質問は少なく, 標準 的な治療方針に関する質問が最多で $59 \%$ を占め，さら に, 遺伝子治療, 免疫療法, 民間療法などの標準治療以 外の治療方針に関する質問が 68 人 $(18 \%)$ であった。こ のうち遺伝子治療に関する質問が 40 人であったが,これ は当院で遺伝子治療を受け付けていたためであろう。ま 
た多くの患者がより有効な治療を探している様子がみら れる.

わが国や欧米では，患者がどのような民間療法を試し ているかを主治医に伝えないのが一般的であるが，世界 の保健サービスの $65 \%$ から $80 \%$ が民間療法の範疇に入 り，欧米においても $20 \%$ から $70 \%$ を占める。米国では $50 \%$ 以上の医師が民間療法を使用または紹介してい る. 4,5 今回の民間療法に関する質問内容は，その有効性 の有無や推薦する民間療法に関してである.

現状の不満を訴える内容として，信頼できる病院を知 りたい転院希望者が 55 人で, 現状に満足していないこと が感じられる．直接の不満意見は 21 人から寄せられた. このうち医師からの説明や意思疎通の問題が 12 人に あった．この内容は，明確な説明をしてもらえないこと や治療方針の説明が納得できないことや，告知に関する ことであった．検査期間が長いことや入院待ちが長いこ とへの不満が 5 人にあった. 医師と患者のコミュニケー ションの問題は少数だが存在する.

不満を持った患者・家族のうちで，手術や化学療法を 既に受けている治療後症例は 34 例であり, 再発が 17 例, III〜IV 期といわれた症例が 8 例であった未治療症例は 33 例で, 内訳は III〜IV 期肺癌が 18 例，手術不可が 5 例であった，不満を抱いた症例の多くは，有効な治療の ない進行した肺癌が占めた，不満を持った症例で手術可 能例の記載はわずか 4 例で，未確診と検査中は 2 例で あった. 多くの症例は有効な治療が選択できない段階で 質問を寄せていることがわかる.

肺癌は早期診断が困難で, 血行転移を特徴とし, 5 年生 存率が $20 \%$ 強であり，そのほとんどが手術例である. 初 診時においても臨床病期 IIIB 以上が $50 \%$ を超えてお り，これらは手術適応外とされ，また僅かな延命効果を 期待した治療しか選択肢がない。このことより肺癌と診 断された，あるいは有効な治療選択肢がないと説明を受 けた患者や家族の気持ちは推し量り難いものである. ${ }^{6}$

医師患者関係において患者が怒りをあらわす状況とし て, 医師の批判的対応や, 外来での長時間の待ち, 検査 の説明不足と苦痛, 入院の長期化などもある. 7 患者は診 断や治療を求めて医師を訪れていることは明白である が，隠れた心理社会的要因があって診察を受けにくるこ とがある. 8 医師患者関係においては, 表面的な問題のみ ならず患者の話したがらない状況が関係を悪化させる要 因となりうる.

米国病院協会は 1973 年に患者の権利章典を制定した. 内容は, 治療を受ける権利, 知る権利, IC を受ける権利, 治療拒否権, プライバシー権, 病院に収容される権利, 臨床試験を受ける権利，医師選択権である.9

癌治療の臨床現場において IC と癌治療は表毫一体を なしている．IC は本来法律的概念として生まれたが，医
の倫理的な性格を含んだものであった. 1964 年の第 18 回世界医師会総会で「ヘルシンキ宣言」が採択され，す でに IC が取り入れられている.今日では医師には説明義 務があるとともに裁量権があり，他方で，患者には真実 を知る権利と自己裁量権があると考えられている。この 両者の均衡をどうとるかは難しいことである．理想的に は患者は医師の専門的能力と判断を尊重し, 医師は患者 の人権と自己決定権を尊重しなくてはならない.10 しか し, 現実の問題として医師側では医療の専門化・細分化 が進行し，医師に説明するだけの時間的余裕がない。一 方，患者側は，マスコミュニケーションやインターネッ トの発達の中で多くの医療情報を直接入手することが可 能になりつつある。次第に医療知識が豊富になり，医師 任せの患者でも分かり易い説明を要求している傾向があ り，医師と患者の間に不満が生じてくる.

セカンドオピニオンとは複数の医師の意見を聞いて最 善の方法を模索するために, 加えて患者が治療法を選択 し, 医師を選択するという基本的人権の保護のために米 国で生まれた概念である.9

インターネットを媒介としたセカンドオピニオン請求 により, 医師と患者間の IC における情報伝達上の多くの 問題点が浮上することを予想していたが, 結果は比較的 良好な医師患者関係がみられた。

癌告知に関して言えば, 米国において 1961 年には, 原 則として癌告知をしない医師が $88 \%$ であったが， 1979 年には $98 \%$ の医師が患者に癌の告知を行っており,大き な変化を示していることがうかがえる.11 本邦の 1990 年の調査では, 日本における医師の患者に対する癌告知 は早期癌では $67 \%$, 進行癌では $16 \%$ である.そして患者 および一般人の告知希望は, 早期癌では $86 \%$, 進行癌で は $71 \%$ であり，現状と大きな相違が認められる.1 その 後の本邦における報告では肺癌患者の $85 \%$ に告知を 行っている施設や, 進行肺癌の告知を 7 割の医師が 50 \%以上行っているという報告があり，本邦での告知率も 次第に増加していると言える. ${ }^{2,12}$ また, 本人が告知を希 望しても家族の反対があることで対応は異なるが，家族 の意見に左右されず患者本人の希望で告知する報告もあ る. 3,13,14 さらに進んで, 告知の是非を議論する段階はも う過ぎてしまったと考え，いかに告知し，その後のフォ ローをするか, その実践的な方法論を高めることが重要 であるという意見や, 15 実際の告知の内容や方法につい ての議論も見受けられる.16,17

癌告知の必要要件は, 日本における公的な基準として, 日本医師会生命倫理委員会の「説明と同意」についての 報告から引用すると，次のとおりである.10

(1)告知の目的がはっきりしていること

(2)患者・家族に受容能力があること

(3)医師およびその他の医療従事者と患者・家族との関 
係がよいこと

(4)告知後の患者の精神的なケア，支援ができること そして，これらの前提条件が整っている場合に限り， 「がん告知」を行うべきことを，十分に知るべきである， とある．実際の臨床の場で, 胸部レントゲン検査で異常 が指摘されたときに，多くの患者は肺癌の可能性を思い 浮かべるはずである．前記の要件を満たさない限り医師 が癌の可能性やその他の説明を差し止めるなら, そして 医師から肺癌の可能性の有無やその他, 病状に関する何 の説明もなく専門病院への紹介や検査が薦められると き，患者がどれほど不安でまた主治医に対する信用をど れほど損なう結果になることかが予想される，患者は自 分が癌なのか他の病気なのか, 治療が必要なのか, 治療 が可能なのかを知りたくて医療機関を訪れるのである. 患者本人に何も知らせず，信頼している家族とこれから 信頼しようと考えている医師が自分の知らないところで 自分の処遇を相談していることを知ったら，患者はどう 思うだろう。一体誰を信頼すればいいのだろう。日本医 師会生命倫理委員会の癌告知の原則が重要なことは理解 できるが, 忘れてならないのは患者が何を求めて医療機 関を訪れているかという大原則である. 実際の癌の可能 性の話や癌告知は診療の場で, 患者の話, 顔つき, 声色, 態度，あらゆる情報を収集し患者の気持ちを考えて行う 必要がある.このときに家族と先に相談しないと何も言 えないのでは，信頼が生まれるはずがない．医師が情報 を正確に伝えることが最良であるということが万人に通 用するとは思わないが, この大原則を忘れてはならない. 今回の分析は個人のプライバシーにかかわる事項を扱 うものであり，インターネットという媒体を使用したこ とにより, 人権問題が生じる可能性がある. そこで, 当 大学の倫理委員会の審議を受けた. その結果, ウェッブ サイト上に質問内容等を論文等に使用する可能性と異議 申し立てを受け付ける旨を公示すること, 今後は電子 メールの暗号化などにより個人情報の安全保護に万全を 期す手段を講ずることを指示された.

\section{結 語}

1. セカンドオピニオン関連の質問では治療方針に関 するものが最多である．肺癌を中心とする胸部悪性腫瘍 の治療に満足できていない.
2. 医師と患者・家族とのコミュニケーションは比較 的良好だが, さらに改善する必要があり, 家族, 特に子 との意思疎通に留意する必要がある。

3. 主治医の治療方針や説明に不安があり, 専門家や専 門病院の情報を欲している。

\section{REFERENCES}

1. 鈴木啓央, 黒坂判造, 金子庄之助, 他. 癌の告知一日本と アメリカ合衆国に㧍ける文献的考察. 日本医事新報. 1992;3543:43-47.

2. 三浦剛史, 松本常男, 田中伸幸, 他. 進行期肺癌患者への 予後告知一アンケートの結果からの検討. 肺癌. 2000;40: 737-741.

3. 大石尚史, 野田康信, 権田秀雄, 他. 肺癌告知 - 治療に対 する患者・家族・医療従事者の認識の相違. 肺癌. 1997; $37: 877-886$.

4. 箕輪良行, 柏井昭良. 患者が銊炎治療について相談してき たとき. Medicina. 1998;35:402-403.

5. Jonas WB. Alternative medicine. J Fam Pract. 1997;45: 34-37.

6. 貫和敏博. 原発性肺癌. 黒川 清, 松澤佑次, 編集. 内科 学. 第 1 版. 東京：文光堂 ; 1999:272-276.

7. 箕輪良行, 柏井昭良. 患者から不満やいら立ちをぶつけら れたら. Medicina. 1997;34:572-573.

8. Barsky AJ 3rd. Hidden reasons some patients visit doctors. Ann Intern Med. 1981;94:492-498.

9. 南雲吉則, 編集. ガンに勝つ法 : セカンドオピニオンのす すめ. 東京：エール出版社；2001:48-68.

10. 日本医師会生命倫理懇談会.「説明と同意」についての報 告. 日本医師会誌. 1990;103:515-535.

11. Novack DH, Plumer R, Smith RL, et al. Changes in physicians' attitudes toward telling the cancer patient. JAMA. 1979;241:897-900.

12. 三浦弘之, 平良 修, 平栗俊介, 他. 肺癌癌告知の現況と その問題点. 日呼吸会誌. 1998;36:963-967.

13. 出月康夫, 笹子三津留. 進行癌患者におけるインフォーム ド・コンセント．日本医師会誌. 1996;115:721-728.

14. 久保田馨. 肺癌治療における informed consent, QOL, cost benefit. 日本臨床. 2000;58:1153-1157.

15. 秋山 修. 肺癌治療におけるインフォームドコンセント. Medical Practice. 1999;16:661-663.

16. Girgis A, Sanson-Fisher RW. Breaking bad news: consensus guidelines for medical practitioners. J Clin Oncol. 1995;13:2449-2456.

17. Butow PN, Kazemi JN, Beeney LJ, et al. When the diagnosis is cancer: patient communication experiences and preferences. Cancer. 1996;77:2630-2637. 